\title{
A. B. ШАРOBA
}

Шарова Антонина Владимировна кандидат исторических наук

доцент, бакультет гуланитарных наук, Национальньй исследовательский университет "Высшая школа эконолики" Россия, 105066, Москва, Старая Басманная ул., 24/1, стр. 3 Тел.: +7 (495) 772-95-90*22898

E-mail: asharova@hse.ru

\section{ПЕРВАЯ МИРОВАЯ ВОЙНА КАК ЛИЧНЫЙ ОПЫТ ИСТОРИКОВ ${ }^{1}$}

\begin{abstract}
Аннотация. В статье рассматриваются личный опыт и восприятие российскими историками, такими как М. М. Ковалевский, А. Н. Савин, Н. И. Кареев, причин, событий и атмосдеры Первой мировой войны. Анализируется изменение отношения академического сообщества к Германии и немцам, затрагивается вопрос о деятельности таких организащий, как Общество сближения с Англией. В статье показывается, как война не только меняет взаимоотношения внутри академического сообщества, но и заставляет интеллектуалов вносить националистические аспекты в свои выступления и печатные издания.
\end{abstract}

Ключевые слова: Первая мировая война, историки, М. М. Ковалевский, А. Н. Савин, Н. И. Кареев, немцы, Англия, Сараевское убийство

И

сториков, как и представителей других научных дисциплин, можно разделять на разные группы: занимающихся политической или экономической историей, периодом Каролингов или Наполеоновской империи, историей зарубежной или отечественной. Отвлекаясь от конкретного поля исследователя или его методологии, можно вспомнить и другие, более оригинальные классификации, например, деление на «ежей» и «лис»². Однако в жизни каждого профессионального сообщества бывают моменты, когда любое деление перестает играть какую-нибудь значимую роль. Таким событием, несомненно, являлась и Первая мировая война. В данном случае наша задача заключается в том, чтобы представить некоторую часть жизни российских

\footnotetext{
${ }^{1}$ Статья подготовлена в результате проведения исследования (№ 17-05-0051) в рамках программы «Научный фонд Национального исследовательского университета "Высшая школа экономики” (НИУ ВШЭ)» в 2017-2018 гг. и в рамках государственной поддержки ведущих университетов Российской Федерации «5-100».

${ }^{2}$ См. подробнее: [Уваров 2015: 242].
} 
«всеобщников» начала XX столетия, не столько научную, сколько обостренно личную и вместе с тем всецело отражающую существовавшие в этот период общие взгляды, стереотипные представления и мнения ученой корпорации. Эта тема - историк и война.

$$
* * *
$$

За последние десятилетия отечественная историография обогатилась значительным числом работ, посвященных жизни и творчеству российских историков. Это касается и М. М. Ковалевского - историка, социолога, правоведа. Однако далеко не все аспекты его мировосприятия получили должное рассмотрение. В частности, исследователи недостаточно внимания уделяют ви́дению им проблем политического развития Европы в начале XX в. и его личному опыту переживания событий Первой мировой войны ${ }^{3}$.

В мае 1915 г. М. М. Ковалевский стал председателем комитета «Русскоанглийского общества», которое обычно называли «Обществом сближения с Англией». Его появление знаменовало институционализацию изменившихся настроений в российском обществе, где в значительной степени начинали превалировать антигерманские настроения в самом широком смысле. Англофилы, равно как и англофобы, были вовсе не редким явлением в российской истории на протяжении XIX-XX вв. И если привлекательность английского парламентаризма и правовых традиций были несомненны для многих в России, то английская внешняя политика, в частности, по отношению в проблеме проливов и на Балканах, в глазах широких слоев российского общества выглядела весьма враждебной. Унижение России в Крымской войне, вмешательство Англии в итоги русско-турецкой войны 1877-1878 гг. - все это лишь способствовало усилению англофобских настроений. Даже создание Антанты не означало полного поворота в общественном сознании в сторону Англии, тем более что англо-бурские войны, весьма остро переживаемые в российском обществе, также не способствовали формированию симпатий по отношению к Британской империи ${ }^{4}$. Наличие исторических предрассудков и плохого знания граждан двух стран друг о друге вынуждены были констатировать и члены собравшегося в 1915 г. «Общества сближения с Англией».

«Общество сближения с Англией» (Anglo-Russian Friendship Society), как отмечали его организаторы, начало создаваться весной 1915 г., когда в Москву приехал М. М. Ковалевский, «только что вернувшийся тогда из австрийского плена» [Отчет 1917: 3]. Широко известный среди зарубежных интеллектуалов, в том числе и как организатор знаменитой Русской школы высших общественных наук в Париже, М. М. Ковалевский стал именно той фигурой, которая символизировала для общества и прогресс, и англофильство, и российскую представительную систему. Действительно, ученый активно работал в качестве члена Государственного совета практически до последних дней своей жизни [Кони 1917: 69-86]. Создание подобного общества в России сто-

\footnotetext{
${ }^{3}$ Некоторое количество исследований в отечественной историографии по проблеме рефлексии историков на события Первой мировой войны все же можно назвать. См., например: [Дмитриев 2001; Иванов 1999; Долгова 2013; Тихонов 2012].

${ }^{4}$ См., например, по этой теме: [Шубин 2001; Davidson, Filatova 1998].

${ }^{5}$ См. об этом подробнее: [Гутнов 2004].
} 
яло на повестке дня тем более, что в Соединенном Королевстве в марте 1915 г. уже было создано «Общество России» (The Russia Society), председателем которого стал спикер палаты общин сэр Джемс Лофтер. Создатели общества в России отмечали особо, что лозунгом британской организации стали слова «A permanent understanding between the British Empire and Russia means permanent peace for the world» ${ }^{6}$. Председателем российского «Общества сближения с Англией» стал М. М. Ковалевский (после его смерти - князь В. М. Голицын). А в 1915 г., в ходе проведения «дней Английского флага» 20-22 ноября, в Петрограде было создано, опять же под председательством М. М. Ковалевского, «Общество Английского флага» (председателем которого после смерти М. М. Ковалевского стал П. Г. Виноградов) [Отчет 1917: 6-7]. Смысл создания этих организаций, по мнению их основателей, заключался прежде всего в том, чтобы через истинные союзнические отношения двух стран, через взаимопонимание «предупредить успешность новых наступательных попыток со стороны Германии» [Отчет 1917: 5], т. е. добиться того, чтобы и после войны англо-франко-русский союз только укреплялся. Таким образом, активная просветительная деятельность англофильских обществ в России, в том числе в сотрудничестве с «Обществом народных университетов», создание при московском обществе библиотеки новейшей английской литературы и периодики, курсов английского языка ${ }^{7}$ - все это должно было способствовать распространению знаний об Англии среди населения и формированию образа союзника из образа старого врага и соперника. Учитывая, что в Англии в этот момент происходило сходное движение, можно сказать, что двум странам действительно удавалось преодолевать прежний порог враждебности.

Однако происходило это на фоне другого явления, характерного не только для обеих стран-союзниц, но и для всех воюющих европейских держав.

В 1914 г. раскол в мире произошел не только между противоборствующими сторонами, ведущими открытые военные действия. Первая мировая война означала и перелом в сознании историков, которым пришлось адаптироваться к изменившимся условиям. Причем речь шла не столько о быте и повседневной жизни, хотя и это представлялось весьма важным, но в первую очередь о необходимости изменения привычных оценочных установок, о расстановке новых акцентов в своих симпатиях и антипатиях, к отказу от многих устоявшихся стереотипов.

Для российских историков, посвятивших свою жизнь изучению западноевропейской истории различных эпох, для университетских профессоров этот перелом был более чем серьезен. Выросшие на традициях немецкой философии и с пиететом относившиеся к немецкой академической культуре, они неожиданно столкнулись с новым для себя явлением - превращением бывших коллег во врагов, а исторической науки - во фронт борьбы идеологий воюющих империй. Собственный опыт, пережитый в начале войны, также немало

${ }^{6}$ «Прочное единение и сближение между Британской империей и Россией означает прочный мир на земле» [Отчет 1917: 4].

${ }^{7}$ В Москве курсы английского языка были организованы по инициативе Софьи Петровны Даль, жены известного в Москве невропатолога, врача университетской клиники Н. В. Даля. Доктор был хорошо известен и в артистических кругах. Его пациентами были С. В. Рахманинов, Ф. И. Шаляпин, К. С. Станиславский, А. Н. Скрябин. 
способствовал трансформации их взглядов. Впрочем, их опыт был далеко не уникальным: историкам Британии и Германии также приходилось заново определять свое положение в этом стремительно менявшемся мире, занимать свое место в борьбе государственных идеологий воюющих стран.

В 1914 г., после начала войны, М. М. Ковалевский взялся за написание воспоминаний. Произошло это после того, как, находясь на лечении в Карлсбаде, ученый, по его словам, «оказался в положении не то гражданского пленного, не то поручителя, с отобранным паспортом и обязательством еженедельно являться в полицию» [Ковалевский 2005: 418]. Интернированный австрийскими властями, он смог вернулся в Россию лишь в феврале 1915 г. $^{8}$

М. М. Ковалевский в воспоминаниях честно признавался, что, несмотря на накал военной риторики в ходе его «славянских» собраний, равно как и обсуждений вопросов внешней политики на заседаниях Государственного совета, значительных ассигнований Российской империи на военные нужды (в том числе на строительство новых дредноутов), он не был готов к тому, что здравый смысл настолько изменит политикам. «Привычка думать, что разум управляет миром, ввела меня в заблуждение», - признавался М. М. Ковалевский [2005: 418]. Из мемуаров становится ясно, что гораздо более ожидаемой датой военного конфликта со странами Тройственного союза для него мог быть 1917 г., когда военные силы России были бы усилены новой техникой. Сараевское убийство рассматривалось им как событие явно случайное, нарушившее логику развития событий.

Впрочем, он вовсе не был одинок в своих ощущениях. А. А. Кизеветтер также замечал, что «никто не подозревал в то же время, что мир находится накануне величайшей из войн. Правда, Балканы кипели... Но как-то никому не думалось, что это только прелюдия к всесветному пожару. И объявление войны налетело как внезапный смерч» [Кизеветтер 1997: 356]. Сходное мнение высказывал и Н. И. Кареев [1990: 261].

Но не только переживание неожиданного начала войны объединило многих историков. Летние месяцы традиционно использовались университетскими профессорами для заграничных командировок, выездов в европейские университеты, библиотеки и архивы, на воды. Поэтому когда война все же была объявлена, значительная часть русской публики оказалась за границей, причем многие - на территории Германской империи или Австро-Венгрии. В Карлсбаде под надзором полиции на полгода оказался М. М. Ковалевский. Некоторые его коллеги считали, что эти события приблизили его преждевременную кончину ${ }^{9}$. Ведь ему «пришлось быть бессильным и связанным в своих действиях, даже заподозренным в “панславистском коварстве", быть свидетелем того, как волна искусственно возбужденного ожесточения смыва-

${ }^{8} \mathrm{O}$ пребывании М. М. Ковалевского в австрийском плену и перенесенных им унижениях подробно написал в сборнике свидетельств россиян, оказавшихся во время начала войны в Германии и в Австрии, а также переживших немецкую и австрийскую оккупацию, А. К. Дживелегов [1915b]. Собственно, сам историк и искусствовед, член партии кадетов А. К. Дживелегов тоже испытал все тяготы австрийского плена - сидел в камерах эгерских казарм во Франценсбаде, а потом и в Вене, спал на соломе, пережил немало унижений [Дживелегов 1915a].

${ }^{9}$ Например, такого мнения придерживался А. Ф. Кони, коллега М. М. Ковалевского по работе в Государственном совете [Кони 1917: 70]. 
ла приобретения человеческой культуры...» [Кони 1917: 85]. Эти месяцы, проведенные вдали от родины, стали для Ковалевского временем воспоминаний о своей жизни, равно как и попыток осмыслить причины разразившейся войны. Пытаясь разобраться в причинах военного конфликта, он нередко прибегал к анализу собственных впечатлений от хода международных дел. Таким образом, война становилась личным переживанием историка не только как ученого, но и как человека, ходом событий непосредственно вовлеченного в нее.

Похожий опыт пришлось пережить в эти осенние месяцы 1914 г. и Н. И. Карееву. Карлсбад, Дрезден, Берлин - Кареев в полной мере столкнулся с проблемами русских, интернированных в Германии. Более того, принял самое непосредственное участие в организации помощи соотечественникам в их возвращении на родину ${ }^{10}$. В письме министру финансов П. Л. Барку он писал:

Объявление войны в субботу, 19 июля / 1 августа, застало врасплох русских путешественников в Германии. Еще накануне газеты уверяли, что мобилизацию русских войск отнюдь не следует признавать явлением, влекущим за собою неизбежное столкновение двух соседних монархий ${ }^{11}$.

Историк уточнял, что в тот же день практически прекратились выплаты денег по аккредитивам в банках Германии, а уже в середине последовал запрет на выезд русских подданных с территории Германии ${ }^{12}$. Понадобилось четыре недели, прежде чем германское правительство приняло решение об отправке русских с территории страны через Швецию. Для поддержки оставшихся без средств к существованию людей были организованы выплаты денежного вспомоществования со стороны как русского императорского правительства, так и правительства Испании, а также пожертвований россиян, постоянно живших за рубежом. Н. И. Кареев принимал активное участие в распределении этих средств и в организации отправки на родину групп соотечественников. Историк отмечал, что страдания интернированным доставляли не только материальные проблемы, но и полная неизвестность в течение нескольких недель относительно собственной судьбы, а также сведения лишь о поразительных победах, одержанных немецкой армией, которыми были заполнены доступные им газеты. «Только в Швеции мы узнали всю правду о наших успехах и неудачах немецких войск на западном фронте войны с нашими союзниками», — вспоминал ученый [Кареев 1915: 20].

Что касается русофобских настроений, то самому Н. И. Карееву пришлось только однажды испытать их на себе, когда один из полицейских чинов в его присутствии обвинял русских в отравлении воды и колодцев [Там же: 11]. Впрочем, русские, по наблюдению историка, не так долго считались главными врагами Германской империи. Вскоре вся ненависть была обращена большей частью на англичан [Там же: 19]. Опыт Кареева оказался особенно ценным и потому, что он сумел наладить отношения с известными ему немецкими

${ }^{10}$ См. подробнее: [Долгова 2013: 126-128].

${ }^{11}$ Цит. по [Долгова 2013: 126].

${ }^{12}$ Пребывание в плену настолько потрясло россиян, что из их рассказов и свидетельств был составлен целый сборник [В немецком плену 1915]. 
коллегами, некоторые из которых приняли деятельное участие в организации жизни и последующего возвращения на родину российских граждан. Рассказывая об этом, Н. И. Кареев открыто высказал свое кредо по отношению к происходившему в мире: война не будет вечной, а после заключения мира должны будут восстановиться добрососедские отношения. Но для того чтобы такое восстановление стало возможным, именно сейчас, в военные годы, надо стремиться к тому, чтобы «избегать с обеих сторон всего, не вытекающего из военной необходимости» [Там же: 15].

Свой опыт возвращения на родину, но только с территории Франции, был и у другого историка - А. Н. Савина. Вот как он вспоминал об этом:

Мне нужно было провести лето в Англии и во Франции. В начале июня я проехал через Берлин... Вечно грубая берлинская железнодорожная прислуга на этот раз была особенно груба, почти нагла, вечно скверный берлинский кофе был на этот раз особенно горек... Может быть, и носильщики с буфетчиками были посвящены в великую тайну?

Прослышав о сараевском убийстве, он «сразу почувствовал всю важность события, но, конечно, сразу не предполагал тогда, что оно приведет к таким огромным и страшным последствиям». Поэтому, мечтая о полноценном отдыхе после напряженного учебного года, А. Н. Савин отправился в Бретань, в спокойное провинциальное местечко ${ }^{13}$.

...С конца июля в газетах пошли известия о столкновении Австрии с Сербией, об австрийских ультиматумах, о вмешательстве России, о серьезных дипломатических осложнениях. Образованные люди моего поколения отлично знают, что Европа постоянно живет на вулкане, что вооруженный мир постоянно угрожает подлинной войной, что немцу тесно в своем милом отечестве и что немец преисполнен безграничного самомнения, и все-таки хотелось отодвинуть подальше Армагеддон. Неужели европейцы ринутся в грозящую страшными бедами войну из-за столкновения пестрой Австрии с маленькой Сербией? ${ }^{14}$

Ученый, как и многие его соотечественники, в том числе М. М. Ковалевский, предпочел надеяться, что решение будет найдено с помощью дипломатических мер. Однако уже 2 августа во Франции появились объявления о всеобщей мобилизации.

Движение пассажирских поездов прекратилось, прервались почтовые и телеграфные сношения, перестал ходить автомобиль, подвозивший нас к ближайшей железнодорожной станции, исчезли газеты. Я оказался прикованным к месту, по крайней мере до конца французской мобилизации. Я не раз читал и слышал о том, что воинская готовность, особенно после возврата к трехлетней службе, лежит на французах гнетущим

${ }^{13}$ ОР РГБ. Ф. 263. Кол. 31. Ед. хр. 6. Л. 1-1 об.

${ }^{14}$ Там же. Л. 1 об. 
бременем, но, признаться, не представлял себе отчетливо всей тяжести этого бремени. Мобилизация показала мне с ужасающей ясностью всю тяжесть навязанного немцами милитаризма. Наш уголок Бретани обезлюдел в несколько дней, ушли чуть ли не все молодые и среднего возраста мужчины. Французские газеты вскоре стали толковать о том, что во время войны нужно принимать все меры к поддержанию промышленности и торговли, что нужно даже отбивать у немцев заокеанские рынки, но о какой промышленности и торговле можно говорить в военное время в стране, где на защиту родины уходят рабочие, служащие, приказчики, бухгалтеры, инженеры, коммивояжеры, директора, хозяева ${ }^{15}$.

Записывая воспоминания об этих днях во Франции уже после возвращения на родину, А. Н. Савин не преминул заметить:

Слава Богу, я очутился в союзной стране, и мне должны были завидовать люди, застигнутые войной в нелюбезной дикой Германии, и все-таки положение получилось незавидное. Французы очень боятся немецких шпионов и, кажется, боятся не без основания 〈...> Как русские, мы стояли выше подозрений, но с объявлением военного положения и мы должны были немедленно явиться в местное полицейское управление и получить разрешение на жительство; если же мы хотели пойти на территорию соседней коммуны, то каждый раз мы должны были в своей мэрии выбирать проходное свидетельство и наклеить свою фотографическую карточку, засвидетельствованную местной администрацией. Для выезда в Англию мы сверх того должны были запастись у помощника префекта удостоверением личности («глаза голубые, лоб открытый, лицо круглое» и т. п.), паспортом на гербовой бумаге, визой английского консула. Приходилось на улице умеренно пользоваться русским языком, потому что местное население плохо различает язык союзников от языка враждебной страны ${ }^{16}$.

Самым сложным, по мнению А. Н. Савина, оказывалось следующее:

...Русский оказался совершенно оторванным от родины и семьи. Он перестал получать газеты, письма, даже телеграммы. Этого мало. Он сразу стал бедным, даже нищим, даже в том случае, если у него в кармане лежали аккредиты на одном из Парижских банков. Одним из главных вопросов для застигнутых войной стал вопрос о том, на что жить и вернуться, как получить деньги с родины.

Даже после того как восстановились телеграфные сношения, получение денег из России продолжало оставаться делом нелегким. Я, например, провел 4 мучительных дня, безуспешно дожидаясь высланных мне из Москвы денег. Я смог вернуться в Россию только благодаря помощи живущих за границей друзей ${ }^{17}$.

${ }^{15}$ Там же. Л. 2-3.

${ }^{16}$ Там же. Л. 3-3 об.

${ }^{17}$ Там же. Л. 3 об.- 4. 
Он отмечал, что бретонцы были готовы предоставить русским жилье в кредит. Интересно, что о таком же отношении некоторых немцев говорил Н. И. Кареев [Долгова 2013: 131]. Наконец, А. Н. Савин с благодарностью вспоминал о деятельности стокгольмского комитета для помощи возвращающимся на родину русским, который организовывал продажу билетов, предлагал денежную помощь нуждающимся ${ }^{18}$. Всего историку понадобилось две недели, чтобы окольными путями вернуться в Россию из Франции. «Впечатлений много, сильных и по большей части тяжелых, - писал в дневнике Савин. - Отрадно было найти в России, и особенно в Москве, подлинный патриотический подъем» [Савин 2015: 345].

Впрочем, далеко не для всех интернированных условия складывались благоприятно. Приват-доцент Московского университета, философ Д. В. Викторов «попал в немецкий плен, выручая свою мать. Мать выпустили, но самого его задержали и отправили в Росток. Там с “пленными” (ультра-штатскими [sic!]) обращались особенно плохо: плохо поместили, очень плохо кормили, так что он быстро нажил себе катар желудка, конвойные приставали к женщинам, когда те выходили в помещавшийся на дворе “кабинет”, женщин и мужчин заставили спать в одном помещении (в школьном здании). Викторову скоро стало так плохо, что он выпросился на частную квартиру. Правда, не везде задержанным было так плохо, как в истинно-мекленбургском Ростоке. Но все-таки в рассказах о немецком варварстве немало правды по свидетельству заслуживающих доверия людей, попавших в немецкие лапы» [Там же: 351-352]. Это свидетельство А. Н. Савин записал в своем дневнике в ноябре 1914 г., не преминув отметить, что еще многие его коллеги продолжали оставаться на немецкой территории ${ }^{19}$.

Таким образом, мы видим, насколько схожими оказывались переживания историков в начале Первой мировой войны. Однако этим опытом им не суждено было ограничиться. В пределах своего воюющего государства каждый оказывался вольно или невольно, но вовлечен в идеологическую борьбу, которая способствовала формированию образа врага и оправданию целей своего воюющего отечества. Историки читали лекции, писали мемуары, рецензировали книги о войне, внося свое переживание в анализ произошедшего в 1914-1918 гг. Помимо этого сами историки оказались вовлечены в военную пропаганду, отстаивая правоту своей стороны. Дипломатические документы, которые немедленно после начала кризиса 1914 г. стали издаваться воюющими сторонами (Белая, Оранжевая, Синяя книги), их переводы и комментарии к ним - все это заставляло историков мобилизовывать свои знания и национальные чувства. Так, в Англии в дни августа-сентября 1914 г. группа историков из Оксфорда создала британскую версию участия в Первой мировой войне. Эта книга, «Why we are at War: Great Britain's Case», предварялась такими словами:

Мы не политики, и мы принадлежим к различным школам политической мысли. Мы написали эту книгу, чтобы изложить причины данной войны и принципы, которые, как мы полагаем, находятся под

${ }^{18}$ Там же. Л. 4 об.

${ }^{19} \mathrm{~B}$ целом о положении пленных в Первую мировую войну см. подробнее: [Оськин 2014]. 
угрозой. У нас есть некоторый опыт в анализе исторических свидетельств, и мы пытались рассматривать этот вопрос исторически ${ }^{20}$ [Barker et al. 1914: 5].

«Исторические» интерпретации ставились на службу государственным интересам ${ }^{21}$. Впрочем, германские историки так же активно участвовали в дискуссии относительно причин войны и их виновников, так что так называемая профессорская война оказалась весьма горячей и ожесточенной. Ответ германских историков на эту книгу появился уже 3 декабря 1914 г., и под ним стояли подписи 26 ученых, среди которых были весьма уважаемые в профессиональном сообществе историки, в частности Герман Онкен, Т. Шиман, Ф. Майнеке и др. [Strandman 2000: 368]. Немецкий историк Ф. Майнеке писал осенью 1914 г.:

Наши оппоненты приписывают нам военные планы создания новой Римской империи - но деревья не растут до небес так быстро 〈...〉 Мы должны прежде всего сокрушить Британию до такой степени, чтобы она признала нас равной себе мировой державой, и я верю, что наша мощь для достижения этой цели достаточна (цит. по: [Галин 2004: 376]).

Когда М. М. Ковалевский в 1914 г. писал свои воспоминания, он не мог обойти стороной начавшийся грандиозный военный конфликт. Сетуя на отсутствие иных изданий, кроме немецких и австрийских газет, он, тем не менее, постарался воспроизвести последовательность событий, восстановить дипломатическую предысторию конфликта. Главная цель, которую ставил перед собой историк, заключалась в том, чтобы понять, может ли война считаться национальной и оборонительной, какой ее провозглашала немецкая пропаганда, каково положение стран в этой войне, каковы их ресурсы и уязвимые позиции. Вывод Ковалевского заключался в том, что ни Россия, ни Англия заранее не готовили эту войну, так что ни о какой заведомой агрессии против Германии не может быть и речи [Ковалевский 2005: 419-422]. При этом он ссылался и на работы о причинах войны, опубликованные германскими профессорами. В частности, его внимание привлек сборник статей «Национальные заявления германских и австрийских историков». Ученый писал:

Надо отдать справедливость немецким профессорам, напечатавшим свои соображения насчет настоящего момента, что поддерживая несомненно из патриотических видов господствующий мотив о том, что война вызвана коварным «Альбионом», вовлекшим в заговор всех завистников германской империи 〈... они в то же время нетнет, да и выскажут догадку, что, мол, обеим империям пришлось на-

${ }^{20}$ «We are not politicians, and we belong to different schools of political thought. We have written this book to set forth the causes of the present war, and the principles which we believe to be at stake. We have some experience in the handling of historic evidence, and we have endeavoured to treat this subject historically».

${ }^{21}$ Подробнее о роли английских историков в военной пропаганде см.: [Strandman 2000: 335-371]. 
чать войну нынешним летом из боязни, что Россия не закончила своих вооружений на средства, оплаченные французской ненавистью [Там же: 424].

Вместе с тем, анализируя неудачный для Стран согласия начальный период войны, М. М. Ковалевский внимательно вчитывался в строки планов относительно предполагаемой судьбы России. «С большой откровенностью духовные руководители германской нации, профессора истории в различных университетах Германии и Австрии» признавали, что Россию ожидает расчленение территории и создание полусамостоятельных государств на ее границах, увеличение за ее счет владений Германской и Австрийской империй. Исходя из этого, М. М. Ковалевский делал вполне закономерный вывод:

России предстоит напрячь все свои силы. Вопрос идет о самом ее существовании, как европейской державы. Все истинные патриоты должны отдать себя этому новому делу освобождения «... Только беззаветно отдавшим себя служению общерусской свободе, без различия партий и направлений $<. . .>$ можно подняться на серьезный отпор самому опасному врагу, какого пока имела Россия [Там же: 440].

Возвращаясь к анализу причин войны и ее целей через несколько месяцев после ее начала на рубеже 1914-1915 гг., М. М. Ковалевский постоянно обращался к соответствующим памфлетам и сборникам статей немецких историков, считая их рупором истинных намерений властей империи [Там же: 441-483].

Однако из сферы исторической и даже пропагандистской эта «профессорская» война в разных государствах скоро начала перерастать в борьбу с представителями самого академического сообщества. Многочисленные памфлеты, посвященные войне, мгновенно переводились на языки противоборствующих сторон, а их авторы становились известны в академических сообществах воюющих держав 22 .

Тем временем 4 октября 1914 г. появляется первый манифест германской профессуры «К культурному миру», подписи под которым поставили 93 человека. 16 октября 1914 г. был опубликован очередной манифест германской профессуры, осуждавший действия союзников против Германии, который подписали более четырех тысяч человек. В свою очередь, в Британии представители академических кругов также активно высказывали свою позицию, обращаясь к общественному мнению страны и Европы ${ }^{23}$. В России в конце сентября 1914 г. было опубликовано коллективное воззвание художников, писателей и артистов, главным содержанием которого было признание необходимости жесткого противостояния германской агрессии [От писателей 1914]. Среди подписавших это обращение были М. Горький, Ф. И. Шаляпин, П. Б. Струве и др. К этому времени стало известно и о бомбежке Страсбургского собора, и об уничтожении знаменитого книгохранилища в Лувене. Немцы, восприни-

${ }^{22}$ Сложную историю взаимоотношений академических сообществ воюющих стран см. подробнее в [Дмитриев 2001; Руткевич 2012].

${ }_{23}^{23}$ Подробнее см.: [Strandman 2000: 366-368]. 
мавшиеся как нация университетов, начинали все больше ассоциироваться с милитаризмом и военными преступлениями. В течение осени 1914 - зимы 1915 г. на памфлеты германских ученых прозвучали ответы интеллектуалов из России, Франции, Англии.

В России появление немецких памфлетов воспринималось академическим сообществом весьма враждебно. Ученые не могли сразу привыкнуть к тому, как быстро бывшие немецкие коллеги превращаются во врагов, подчас не замечая, что подобная метаморфоза на волне национального (в некоторых случаях даже с привкусом шовинизма) подъема захватывает и их. Вряд ли ранее тот же М. М. Ковалевский мог позволить себе серьезно говорить о том, что Германия и Австро-Венгрия «стеной отделяли нас от непосредственного обмена не одними товарами, но и идеями от Британской империи» [Дживелегов 1915c: 8].

В то же время именно М. М. Ковалевский решился возглавить важный для российских интеллектуалов патриотический проект - издание специальных сборников под общим названием «Россия и ее союзники в борьбе за цивилизацию» (со 2-го тома — «Европа и война. Россия и ее союзники в борьбе за цивилизацию») [Россия 1916-1917]. Эти сборники, где печатались статьи многих российских историков, в том числе Н. И. Кареева, Э. Д. Гримма, Е. В. Тарле, должны были показать прежде всего историю взаимоотношений Германии с другими странами, а также историю войн, которые вела Россия в Европе. Иллюстрации к этому изданию делали художники Е. Е. Лансере, М. В. Добужинский, К. Е. Маковский.

Взаимная ненависть, в разжигании которой ученые приняли не последнее по значимости участие, нарастала быстро. В августе 1914 г. некоторые из германских ученых отказались от наград и званий, полученных ими от британских коллег [Strandman 2000: 349]. Впрочем, так же поступили и французские ученые, прервав свое членство в немецких университетах и обществах.

В России антинемецкие настроения подчас принимали самые яркие формы. Прозвучал призыв не печатать трудов на немецком языке и в немецких изданиях. 31 октября 1914 г. Совет министров издал положение «Об исключении подданных воюющих с Россией держав из состава союзов и обществ», в результате чего только из числа профессоров Московского университета были исключены около 70 подданных Германии ${ }^{24}$.

Еще в начале октября 1914 г. историк А. Н. Савин записывал в дневнике:

...Я радуюсь всему, что хоть в некоторой степени способствует русскому освобождению от немцев, которых, кстати сказать, я очень высоко ставлю, несмотря на всю их противность [Савин 2015: 348].

Спустя месяц этот толерантный человек вдруг выяснил, что его друг, «русский немец» по происхождению, профессор кафедры финансового права Московского университета Павел Петрович Гензель (Павел-Юлий-АльфонсХристофор), оказавшись в Германии, «проявил удивительное германофильство и открыто пророчил победу немцам, что, несмотря на войну, он старался поддерживать хорошие отношения с тамошними немецкими властями». «Я понимаю трудность его положения, — продолжал А. Н. Савин. - Но на

${ }^{24}$ См. подробнее: [Иванов 1999: 108-127]. 
войне русские немцы должны покончить со своим сиденьем на двух стульях». Историк принял решение «отойти» от дружбы с этим «мягким немцем» [Там же: 352]. Так война разрушала даже дружеские связи внутри академического сообщества, оказавшегося столь же подверженным идеологии государственного патриотизма, как и все общество воюющих держав.

Впрочем, не всегда шовинистическому угару удавалось захлестнуть представителей академического сообщества. Так, Н. И. Кареев в декабре 1914 г. отказался подписать известный «Ответ германским ученым», под которым поставили подпись многие профессора Москвы и Петрограда [Дмитриев 2001: 310]. Узнав из газет о том, что знаменитого немецкого психолога Вильгельма Вундта исключили из почетных членов Московского университета, А. Н. Савин в дневнике записал:

Нужно ли было исключать? Сомневаюсь. Вероятно, лучше было бы разделять патриотизм и чистое знание и не следовать дурному немецкому примеру [Савин 2015: 354].

Тем временем у российского общественного мнения появлялись новые герои. В декабре 1914 г. почетными членами Московского университета стали верховный главнокомандующий войск Российской империи великий князь Николай Николаевич и король Бельгии Альберт I, который прославился организацией героического сопротивления германским войскам, в частности, с помощью затопления части территории Бельгии. В 1916 г. посол Британии в России Дж. Бьюкенен стал почетным гражданином Москвы.

В связи с началом войны с Германией 18 августа 1914 г. столица Российской империи была переименована из Санкт-Петербурга в Петроград. После такого неожиданного патриотического переименования А. Н. Савин в дневнике писал новое название города в кавычках. Через три года, в июле 1917 г., на фоне утвердившихся в обществе антигерманских настроений в Англии было изменено название правящей династии. Вместо Саксен-Кобург-Готской династии по решению Георга V появилась династия Виндзоров. Власти стран Антанты избавлялись от немецкого наследства, а сообщество историков столкнулось с серьезной проблемой преобладания национального, даже правильнее будет сказать, националистического духа в своем профессиональном поле.

\section{Литература}

В немецком плену 1915 - В немецком плену. М.: Наши дни, 1915.

Галин 2004 - Галин В. В. Война и революция. М.: Алгоритм, 2004.

Гутнов 2004 - Гутнов Д. А. Русская высшая школа общественных наук в Париже (19011906 гг.). М.: РОССПЭН, 2004.

Дживелегов 1915a - Дживелегов A. В австрийском плену // В немецком плену. М.: Наши дни, 1915. С. 68-73.

Дживелегов $1915 \mathrm{~b}$ - Джсиелегов A. М. М. Ковалевский в плену // В немецком плену. М.: Наши дни, 1915. С. 21-23.

Дживелегов 1915с - Россия и Англия: Речи, произнесенные на торжественном открытии Общества сближения с Англией в Москве, 22 мая 1915 г. / Под ред. и с предисл. А. К. Дживелегова. М.: О-во сближения с Англией, 1915. 
Дмитриев 2001 - Дмитриев А. Н. Мобилизация интеллекта: Первая мировая война и международное научное сообщество // Интеллигенция в истории: Образованный человек в социальных представлениях и действительности / [Отв. ред. Д. А. Сдвижков]. М.: ИВИ РАН, 2001. С. 196-335.

Долгова 2013 - Долгова Е. А. «Свое право писать... я обосновал на нашем товариществе по науке»: деятельность Н. И. Кареева в Комитете по оказанию помощи русским в Германии. 1914 г. // Исторический архив. 2013. № 3. С. 126-136.

Иванов 1999 - Иванов А. E. Российское «ученое сословие» в годы «второй Отечественной войны». Очерк гражданской психологии и патриотической деятельности // Вопросы истории естествознания и техники. 1999. № 2. С. 108-127.

Кареев 1915 - Кареев Н. И. Пять недель в германском плену // В немецком плену. М.: Наши дни, 1915. С. 11-20.

Кареев 1990 - Кареев Н. И. Прожитое и пережитое. Л.: Изд-во ЛГУ, 1990.

Кизеветтер 1997 - Кизеветтер А. А. На рубеже двух столетий. Воспоминания, 1881 1914. М.: Искусство, 1997.

Ковалевский 2005 - Ковалевский М. М. Моя жизнь: Воспоминания. М.: РОССПЭН, 2005.

Кони 1917 - Кони А. Ф. М. М. Ковалевский в Государственном Совете // М. М. Ковалевский. Ученый, государственный и общественный деятель и гражданин: Сб. ст. Пг: Артист. заведение т-ва А. Ф. Маркс, 1917. С. 69-86.

Оськин 2014 - Оськин М. В. Неизвестные трагедии Первой мировой. Пленные. Дезертиры. Беженцы. М.: Вече, 2014.

От писателей 1914 - От писателей, художников и артистов // Русские ведомости. 1914. 28 сент.

Отчет 1917 - Отчет о деятельности Общества сближения с Англией. 1 год. 22 мая 1915 - 1 ноября 1916 г. М.: [б. и.], 1917.

Россия 1916-1917 - Россия и ее союзники в борьбе за цивилизацию. Т. 1-3. М.: Изд. Д. Я. Маковского, 1916-1917.

Руткевич 2012 - Руткевич А. М. Идеи 1914 года: Препринт WP6/2012/03. М.: НИУ ВШЭ, 2012.

Савин 2015 - Савин А. Н. Университетские дела. Дневник 1908-1917 / Отв. ред. А. К. Гладков; Публ., вступ. ст. А. В. Шаровой. М.; СПб.: Центр гуманитарных инициатив, 2015.

Тихонов 2012 - Тихонов В. В. Пропаганда прошлым: российские историки в годы Первой мировой войны // Электронный научно-образовательный журнал «История». Т. 3. Вып. 3(11). 2012. URL: https://history.jes.su/s207987840000390-8-1.

Уваров 2012 - Уваров П. Ю. Между «ежами» и «лисами»: восприятие творчества Ле Руа Ладюри в СССР и России // Уваров П. Ю. Между «ежами» и «лисами»: Заметки об историках. М.: Нов. лит. обозрение, 2015. С. 242-260.

Шубин 2001 - Шубин Г. В. «Желаю отправиться в Южную Африку...» Участие русских офицеров-добровольцев в англо-бурской войне 1899-1902 гг. // Военно-исторический журнал. 2001. № 2. С. 67-77.

Barker et al. 1914 - [Barker E. et al. $]$ Why we are at war: Great Britain's case. Oxford: Clarendon Press, 1914.

Davidson, Filatova 1998 - Davidson A., Filatova I. The Russians and the Anglo-Boer War, 1899-1902. Cape Town: Human \& Rousseau, 1998.

Strandman 2000 - Strandman H. P. von. The role of British and German historians in mobilizing public opinion in 1914 // British and German historiography, 1750-1950. Traditions, perceptions, and transfers / Ed. by B. Stuchtey, P. Wende. Oxford; New York: Oxford Univ. Press, 2000. P. 335-371. 


\title{
Сокращения
}

ОР РГБ - Отдел рукописей Российской государственной библиотеки.

\section{THE FIRST WORLD WAR AS PERSONAL EXPERIENCE OF HISTORIANS}

\author{
Sharova, Antonina V. \\ PhD (Candidate of Science in History) \\ Associate Professor \\ Faculty of Humanities, School of History, \\ National Research University Higher School of Economics \\ Russia, 105066, Moscow, Staraya Basmannaya str., 24/1, build. 3 \\ Tel.: +7 (495) 772-95-90*22898 \\ E-mail: asharova@hse.ru
}

\begin{abstract}
The article considers the personal experience and perception by Russian historians, such as M. M. Kovalevsky, A. N. Savin, and N. I. Kareev, of the causes, events and atmosphere of the First World War. The change in the attitude of the academic community to Germany and the Germans is analyzed, and the activities of such organizations as the "Anglo-Russian Friendship Society" and assistance to Russian citizens who'd been caught in captivity are discussed. The article deals with the problem of the influence of war on the academic society, the transformation of relations between intellectuals depending on their nationality. The personal experience of historians who survived captivity in Germany or Austria-Hungary, the difficulties experienced by Russians on the way to Russia through a warring Europe, all this forced intellectuals to see a new relationship of the warring countries, which was reflected in their public speeches and sociopolitical position. The author seeks to show that the so-called" war of professors " contributed to the development of nationalist traits in Russian historical science.
\end{abstract}

Keywords: The First World War, historians, M. M. Kovalevsky, A. N. Savin, N. I. Kareev, Germans, England, Sarajevo murder

\section{References}

[Barker, E., et al.] (1914). Why we are at war: Great Britain's case. Oxford: Clarendon Press.

Davidson, A., Filatova, I. (1998). The Russians and the Anglo-Boer War, 1899-1902. Cape Town: Human \& Rousseau.

Dmitriev, A. N. (2001). Mobilizatsiia intellekta: Pervaia mirovaia voina i mezhdunarodnoe nauchnoe soobshchestvo [Mobilization of the intellect: World War I and the international scientific community]. In D. A. Sdvizhkov (Ed.). Intelligentsiia v istorii: Obrazovannyi chelovek $v$ sotsial'nykh predstavleniiakh i deistvitel'nosti [Intellectuals in history: The educated person in social representations and reality], 196-335. Moscow: IVI RAN. (In Russian).

Dolgova, E. A. (2013). "Svoe pravo pisat'... ia obosnoval na nashem tovarishchestve po nauke": deiatel'nost' N. I. Kareeva v Komitete po okazaniiu pomoshchi russkim v Germanii. 1914 g. 
["I have justified my right to write... on our partnership in science": N. I. Kareev in the Committee to Assist Russians in Germany, 1914]. Istoricheskii arkhiv [Historical archive], 2013(3), 126-136. (In Russian).

Dzhivelegov, A. (1915a). V avstriiskom plenu [In Austrian captivity]. In V nemetskom plenu [In the German captivity], 68-73. Moscow: Nashi dni. (In Russian).

Dzhivelegov, A. (1915b). M. M. Kovalevskii v plenu [M. M. Kovalevsky in captivity]. In $V$ nemetskom plenu [In German captivity], 21-23. Moscow: Nashi dni. (In Russian).

Dzhivelegov, A. K. (Ed., Intro.) (1915c). Rossiia i Angliia: Rechi, proiznesennye na torzhestvennom otkrytii Obshchestva sblizheniia s Angliei v Moskve, 22 maia $1915 \mathrm{~g}$. [Russia and England: Speeches delivered at the inauguration of the Society for Rapprochement with England, in Moscow, May 22, 1915]. Moscow: Obshchestvo sblizheniia s Angliei. (In Russian).

Galin, V. V. (2004). Voina i revoliutsiia [War and revolution]. Moscow: Algoritm. (In Russian).

Gutnov, D. A. (2004). Russkaia vysshaia shkola obshchestvennykh nauk v Parizhe (19011906 gg.). [Russian Higher School of Social Sciences in Paris (1901-1906)]. Moscow: ROSSPEN. (In Russian).

Ivanov, A. E. (1999). Rossiiskoe "uchenoe soslovie" v gody "vtoroi Otechestvennoi voiny". Ocherk grazhdanskoi psikhologii i patrioticheskoi deiatel'nosti [The Russian "learned estate" during the "Second Patriotic War": Essay on civil psychology and patriotic activity]. Voprosy istorii estestvoznaniia i tekhniki [Questions of the history of natural science and technology], 1999(2), 108-127. (In Russian).

Kareev, N. I. (1915). Piat' nedel'v germanskom plenu [Five weeks in German captivity]. In V nemetskom plenu. (1915) [In German captivity], 11-20. Moscow: Nashi dni. (In Russian).

Kareev, N. I. (1990). Prozhitoe i perezhitoe [The lived and the experienced]. Leningrad: Izdatel'stvo LGU. (In Russian).

Kizevetter, A. A. (1997). Na rubezhe dvukh stoletii: Vospominaniia, 1881-1914 [At the turn of two centuries. Memoirs, 1881-1914]. Moscow: Iskusstvo. (In Russian)

Koni, A. F. (1917). M. M. Kovalevskii v Gosudarstvennom Sovete [M. M. Kovalevsky in the State Council]. In M. M. Kovalevskii. Uchenyi, gosudarstvennyi i obshchestvennyi deiatel' i grazhdanin: Sbornik statei [M. M. Kovalevsky. Scholar, state and public figure, and citizen: Collection of articles], 69-86. Petrograd: Artisticheskoe zavedeniie tovarishchestva A. F. Marks. (In Russian).

Kovalevskii, M. M. (2005). Moia zhizn': Vospominaniia [My life: Memoirs]. Moscow: ROSSPEN. (In Russian).

Os'kin, M. V. (2014). Neizvestnye tragedii Pervoi mirovoi. Plennye. Dezertiry. Bezhentsy [Unknown tragedies of the First World War. Prisoners. Deserters. Refugees]. Moscow: Veche. (In Russian).

Ot pisatelei, khudozhnikov i artistov (1914, September 28) [From writers, painters and artists]. Russkie vedomosti [Russian Gazette]. (In Russian).

Otchet o deiatel'nosti Obshchestva sblizheniia s Angliei. 1 god. 22 maia 1915 - 1 noiabria 1916 g. (1917) [Report on the activities of the Society for Rapprochement with England. $1^{\text {st }}$ year. May 22, 1915 - November 1, 1916]. Moscow: [n. p.]. (In Russian)

Rossiia i ee soiuzniki v bor'be za tsivilizatsiiu (1916-1917) [Russia and its allies in the struggle for civilization] (Vols. 1-3). Moscow: Izdanie D. Ia. Makovskogo. (In Russian).

Rutkevich, A. M. (2012). Idei 1914 goda [Ideas of 1914] (preprint WP6/2012/03). Moscow: NIU VShE. (In Russian).

Savin, A. N. (2015). Universitetskie dela. Dnevnik 1908-1917 [University affairs. Diary for 1908-1917]. A. K. Gladkov (Ed.). A. V. Sharova (Publ., Intro.). Moscow; St. Petersburg: Tsentr gumanitarnykh initsiativ. (In Russian). 
Shubin, G. V. (2001). “Zhelaiu otpravit'sia v Iuzhnuiu Afriku...” Uchastie russkikh ofitserovdobrovol'tsev v anglo-burskoi voine 1899-1902 gg. ["I wish to go to South Africa..." The participation of Russian volunteer officers in the Anglo-Boer War of 1899-1902]. Voenno-istoricheskii zhurnal [Journal of Military History], 2001(2), 67-77. Moscow: (In Russian).

Strandman, H. P. von (2000). The role of British and German historians in mobilizing public opinion in 1914. In B. Stuchtey, P. Wende (Eds.). British and German historiography, 1750-1950. Traditions, perceptions, and transfers, 335-371. Oxford; New York: Oxford Univ. Press.

Tikhonov, V. V (2012). Propaganda proshlym: rossiiskie istoriki v gody Pervoi mirovoi voiny [Propaganda of the past: Russian historians during the First World War]. Elektronnyi nauchno-obrazovatel'nyi zhurnal "Istoriia" [The Journal of Education and Science "ISTORIYA" ("History")], 3(3[=11]). Retrieved from https://history.jes.su/ s207987840000390-8-1.

Uvarov, P. Iu. (2015). Mezhdu "ezhami" i "lisami”: vospriiatie tvorchestva Le Rua Ladiuri v SSSR i Rossii [Between "hedgehogs" and "foxes": Reception of the writings of Le Roy Ladurie in the USSR and Russia]. In P. Iu. Uvarov. Mezhdu "ezhami" $i$ "lisami": Zametki ob istorikakh [Between "hedgehogs" and "foxes": Notes about historians], 242-260. Moscow: Novoe literaturnoe obozrenie. (In Russian).

V nemetskom plenu. (1915) [In German captivity]. Moscow: Nashi dni. (In Russian).

To cite this article:

Sharova, A. V. (2018). Pervaia mirovaia voina KaK lichnyi opyt istorikov [The First World War as personal experience of historians]. Shagi / STEPS, 4(2), 150-165. (IN RUSSIAN). 